\title{
PELAYANAN PRIMA PADA RUMAH SAKIT UMUM MILIK PEMERINTAH DI JAWA \\ (Studi di Rumah Sakit Umum Pusat Dr. Kariadi Semarang, Rumah Sakit Umum Daerah Dr. Soetomo Surabaya, dan Rumah Sakit Umum Pusat \\ Dr. Hasan Sadikin Bandung)
}

\author{
Hesti Lestari ${ }^{1}$
}

\begin{abstract}
Hospital services are basically a form of service provided to patients by paying attention to predetermined service quality standards, in order to create satisfaction for patients in accordance with patient expectations. Central General Hospital Dr. Kariadi Semarang, Regional General Hospital Dr. Soetomo Surabaya, and Central General Hospital Dr. Hasan Sadikin Bandung is a government-owned public hospital located in the Java region. The three hospitals are government-owned hospitals as national referral hospitals which are class A hospitals. The purpose of this research is to find out how the form of excellent service and the advantages and disadvantages of the Central General Hospital Dr. Kariadi Semarang, Regional General Hospital Dr. Soetomo Surabaya and Central General Hospital Dr. Hasan Sadikin Bandung. The research method used the desk-review method, namely the collection of secondary data or data that has been previously collected without conducting a field survey and library research methods. Besides that, this research also uses literature study, namely collecting scientific papers or collecting data related to the object of research or collecting library data. The form of excellent service carried out by the Central General Hospital Dr. Kariadi Semarang, Regional General Hospital Dr. Soetomo Surabaya and Central General Hospital Dr. Hasan Sadikin Bandung is about speed of service, accuracy of service, accurate service and quality of service. Each hospital has problems regarding the speed of service, so that the speed of service is a priority for improvement for hospitals to realize excellent service in accordance with patient expectations.
\end{abstract}

Keywords: Health Service; Excellent Service; Hospital

\section{PENDAHULUAN}

Berdasarkan amanat Pasal 28H Undang-undang Dasar Negara Republik Indonesia Tahun 1945 (UUD 1945) menyatakan bahwa setiap orang berhak hidup sejahtera lahir dan batin, bertempat tinggal dan mendapatkan lingkungan hidup yang baik dan sehat serta berhak memperoleh pelayanan kesehatan tanpa ada unsur diskriminasi dalam memenuhi pelayanan kesehatan bagi masyarakat. Pelayanan kesehatan merupakan salah satu hak

\footnotetext{
${ }^{1}$ Departemen Administrasi Publik, FISIP, Universitas Diponegoro
} 
asasi manusia yang harus dipenuhi oleh negara bagi seluruh masyarakat Indonesia. Indonesia memiliki fasilitas kesehatan yang pengelolaannya bersifat padat modal, padat karya dan padat teknologi, yakni rumah sakit. Rumah sakit merupakan mata rantai rujukan pelayanan kesehatan yang memiliki peran strategis dalam meningkatkan derajat kesehatan masyarakat dan dianggap mampu memberikan kualitas pelayanan terbaik (Herlambang dan Murwani, 2012).

Keputusan Menteri (Kepmen) Pendayagunaan Aparatur Negara Nomor 63 tahun 2003 tentang Pedoman Umum Penyelenggaraan Pelayanan Publik menyebutkan bahwa hakikat pelayanan publik seperti rumah sakit ialah pemberian pelayanan prima kepada masyarakat. Pelayanan prima dalam konteks pelayanan rumah sakit berarti pelayanan yang diberikan kepada pasien berdasarkan standar kualitas untuk memenuhi kebutuhan dan keinginan pasien sehingga pasien dapat memperoleh kepuasan yang akhirnya dapat meningkatkan kepercayaannya kepada rumah sakit (Endarini, 2001). Menurut Daryanto dan Setyobudi (2014), pelayanan prima merupakan terjemahan dari istilah "excellent service" yang memiliki arti pelayanan terbaik atau sangat baik. Pelayanan prima disebut sangat baik atau terbaik karena sesuai dengan standar pelayanan yang dimiliki instansi pemberi pelayanan.

Menurut Surjadi (2009), indikator dalam menentukan pelayanan prima yang diberikan kepada masyarakat, pada dasarnya mencakup empat indicator, yaitu: 1. Cepat, memiliki arti bahwa artinya proses pelayanan yang diberikan cepat dan pengguna layanan tidak membutuhkan waktu tunggu yang lama. 2. Tepat, artinya bahwa dalam memberikan pelayanan harus tepat sasaran, kualitas maupun kuantitas serta kompetensi pegawai. 3. Akurat, memiliki pengertian bahwa produk pelayanan tidak mengandung kesalahan dan sudah pasti kebenaranya. 4. Berkualitas, yaitu kualitas pelayanannya sesuai dengan keinginan, berpihak dan untuk kepentingan masyarakat khusunya dalam kualitas sarana dan prasarana.

Rumah Sakit Umum Pusat Dr. Kariadi Semarang, Rumah Sakit Umum Daerah Dr. Soetomo Surabaya, dan Rumah Sakit Umum Pusat Dr. Hasan Sadikin Bandung merupakan rumah sakit umum milik pemerintah yang berada di wilayah Jawa yang merupakan rumah sakit kelas A. Adapun daftar rumah sakit rujukan dan kelas di Jawa dapat dilihat pada tabel berikut: 
Tabel 1. Rumah Sakit, Kelas, dan Rujukan di Jawa

\begin{tabular}{|c|c|c|c|}
\hline Nama & Provinsi & Kelas & Rujukan \\
\hline RS Umum Pusat Dr. Kariadi & Jawa Tengah & A & Rujukan nasional \\
\hline $\begin{array}{l}\text { RS Umum Daerah Prof Dr. Margono } \\
\text { Soekarjo Purwokerto }\end{array}$ & Jawa Tengah & B & Rujukan regional \\
\hline RS Umum Daerah RAA Soewondo & Jawa Tengah & B & Rujukan regional \\
\hline RS Umum Daerah Tidar & Jawa Tengah & $\mathrm{B}$ & Rujukan regional \\
\hline RS Umum Daerah Dr. Moewardi Surakarta & Jawa Tengah & A & Rujukan regional \\
\hline RS Umum Daerah Tugurejo Semarang & Jawa Tengah & B & Rujukan regional \\
\hline RS Umum Daerah Kraton Kab. Pekalongan & Jawa Tengah & B & Rujukan regional \\
\hline RS Umum Daerah Kardinah & Jawa Tengah & $\mathrm{B}$ & Rujukan regional \\
\hline RS Umum Daerah Dr. Soetomo & Jawa Timur & $\mathbf{A}$ & Rujukan nasional \\
\hline RS Umum Daerah Dr. Soebandi & Jawa Timur & B & Rujukan regional \\
\hline RS Umum Daerah Kab. Jombang & Jawa Timur & B & Rujukan regional \\
\hline RS Umum Daerah Ibnu Sina Kab. Gresik & Jawa Timur & B & Rujukan regional \\
\hline RS Umum Daerah Dr. Saiful Anwar & Jawa Timur & A & Rujukan regional \\
\hline RS Umum Daerah Dr. Soedono Madiun & Jawa Timur & $\mathrm{B}$ & Rujukan regional \\
\hline RS Umum Haji Surabaya & Jawa Timur & B & Rujukan regional \\
\hline RS Umum Pusat Dr. Hasan Sadikin & Jawa Barat & $\mathbf{A}$ & Rujukan nasional \\
\hline RS Umum Daerah dr. Soekardjo & Jawa Barat & B & Rujukan regional \\
\hline RS Umum Daerah Cibinong & Jawa Barat & B & Rujukan regional \\
\hline RS Umum Daerah Cibabat & Jawa Barat & B & Rujukan regional \\
\hline $\begin{array}{l}\text { RS Umum Daerah A1 Ihsan Provinsi Jawa } \\
\text { Barat }\end{array}$ & Jawa Barat & B & Rujukan regional \\
\hline RS Umum Daerah Karawang & Jawa Barat & $\mathrm{B}$ & Rujukan regional \\
\hline RS Umum Daerah R Syamsudin SH & Jawa Barat & B & Rujukan regional \\
\hline RS Umum Daerah Gunung Jati & Jawa Barat & $\mathrm{B}$ & Rujukan regional \\
\hline
\end{tabular}

Sumber: Olah Data Penulis Tahun 2021

Tiga rumah sakit umum milik pemerintah tersebut menjadi pilihan sebagian masyarakat di Kota maupun Provinsi untuk memperoleh pelayanan kesehatan karena rumah sakit tersebut memiliki sarana dan prasarana yang lebih mendukung dan memadai. Selain itu, ketiga rumah sakit tersebut merupakan rumah sakit rujukan nasional di Jawa yang terakreditasi dengan status akreditasi “tingkat paripurna”. Tingkat paripurna adalah tingkat kelulusan tertinggi yang dapat diraih oleh rumah sakit sehingga pelayananya dinilai lebih unggul. Tujuan penulisan adalah untuk mengetahui bentuk pelayanan prima di Rumah Sakit Umum Pusat Dr. Kariadi Semarang, Rumah Sakit Umum Daerah Dr. Soetomo Surabaya, Rumah Sakit Umum Pusat Dr. Hasan Sadikin Bandung dan untuk mengetahui kelebihan dan kekurangan pelayanan prima di Rumah Sakit Umum Pusat Dr. Kariadi Semarang, Rumah Sakit Umum Daerah Dr. Soetomo Surabaya dan Rumah Sakit Umum Pusat Dr. Hasan Sadikin Bandung.

\section{METODE PENELITIAN}

Metode penelitian dalam tulisan ini menggunakan metode desk-review dengan mengacu pada definisi menurut Hague dkk (2013), yakni pengumpulan data sekunder atau data-data yang telah dikumpulkan sebelumnya dengan metode studi kepustakaan (library research). Studi Pustaka, yaitu mengumpulkan karya tulis ilmiah atau 
mengumpulkan data yang berkaitan dengan objek penelitian atau pengumpulan data bersifat kepustakaan (Nazir, 2014). Data-data yang sudah didapatkan, dihubungkan untuk mendapatkan pemahaman yang lebih mendalam. Adapun jenis data yang dikumpulkan dalam penelitian ini berupa data dari penelitian orang lain yang sejenis, artikel di internet, referensi buku, data yang berkaitan, jurnal dan laporan-laporan mengenai topik yang berkaitan dengan penelitian dan website resmi yang dipublikasikan oleh badan atau LSM seperti milik Kementrian Kesehatan, Dinas Kesehatan, dan masingmasing milik Rumah Sakit. Metode analisis yang digunakan dalam penelitian ini adalah analisis interaktif dengan tiga komponen analisis, yaitu reduksi data, penyajian data, dan menarik kesimpulan (Sugiyono, 2011).

\section{HASIL DAN PEMBAHASAN}

\section{A. Cepat (Kecepatan Pelayanan)}

Kecepatan pelayanan untuk mewujudkan pelayanan prima mengandung arti, yakni kemampuan untuk memberikan pelayanan secara cepat dan tidak membutuhkan waktu tunggu yang lama untuk mendapatkan pelayanan yang dibutuhkan.

1. Rumah Sakit Umum Pusat Dr. Kariadi Semarang

Capaian nilai indikator kinerja individu selama tahun 2020 berdasarkan Laporan Tahun 2020 Rumah Sakit Umum Pusat Dr. Kariadi Semarang, memperoleh nilai IKI sebesar 2 dari 18 indikator, terdapat 3 indikator yang masih belum mencapai standar, yaitu waktu lapor hasil test kritis laboratorium, ketepatan identifikasi pasien dan waktu tunggu pelayanan resep obat jadi. Penyebab indikator waktu tunggu hasil test kritis laboratorium belum tercapai disebabkan karena untuk menyampaikan hasil kritis kepada DPJP harus melalui beberapa tahapan (perawat dan atau asisten DPJP) yang mengetahui kondisi secara langsung pasiennya, dan bila dapat laporan hasil kritis dapat langsung melakukan advis DPJP. Selain itu, dari segi waktu tunggu pelayanan resep obat jadi belum mencapai standar karena adanya penumpukan resep pada jam tertentu sehingga waktu tunggu menjadi lebih lama karena ada beberapa DPJP yang tidak sesuai jadwal jam praktek, dan keterbatasan jumlah SDM (apoteker) dalam melayani pelayanan farmasi. 
2. Rumah Sakit Umum Daerah Dr. Soetomo Surabaya

Permasalahan mengenai kecepatan pelayanan di RSUD Dr. Soetomo Surabaya dijumpai pada pelayanan penunjang MRI. Pernyataan tersebut didukung oleh data pada tabel berikut:

Tabel 2. Pelayanan MRI RSUD Dr. Soetomo Tahun 2018

\begin{tabular}{|l|c|c|c|c|}
\hline \multicolumn{1}{|c|}{ Bulan } & $\begin{array}{c}\text { Target } \\
\text { Pelayanan }\end{array}$ & $\begin{array}{c}\text { Jumlah Permintaan } \\
\text { Pelayanan MRI }\end{array}$ & $\begin{array}{c}\text { Jumlah Pasien } \\
\text { dilayani }\end{array}$ & $\begin{array}{c}\text { Jumlah Antrian } \\
\text { Pelayanan MRI }\end{array}$ \\
\hline Januari & 315 & 440 & 358 & 82 \\
\hline Februari & 285 & 380 & 287 & 93 \\
\hline Maret & 315 & 380 & 353 & 27 \\
\hline April & 139 & 200 & 259 & 59 \\
\hline Mei & 300 & 400 & 303 & 97 \\
\hline Juni & 180 & 220 & 165 & 55 \\
\hline Juli & 330 & 440 & 352 & 87 \\
\hline Agustus & 315 & 420 & 333 & 92 \\
\hline September & 285 & 380 & 288 & 52 \\
\hline Oktober & 345 & 460 & 408 & 6 \\
\hline November & 315 & 400 & 394 & $\mathbf{6 3 5}$ \\
\hline Desember & 285 & 360 & 345 & $\mathbf{3 8 4 5}$ \\
\hline Total & $\mathbf{3 4 0 9}$ & $\mathbf{4 4 8 0}$ &
\end{tabular}

Sumber: Rencana Strategis RSUD Dr. Soetomo Tahun 2019-2024

Rata-rata setiap bulan pada tahun 2018 selalu ada sisa antrian pasien yang memerlukan pelayanan MRI karena jumlah permintaan pelayanan MRI yang selalu melebihi target pelayanan MRI sehingga masih terdapat pasien yang tidak dapat dilayani tepat waktu sesuai penjadwalan. Hal tersebut menggambarkan perlunya penambahan alat MRI, yang juga mendukung pengembangan RSUD Dr. Soetomo untuk menjadi rumah sakit rujukan nasional yang salah satunya adalah Pengembangan Layanan Kanker.

Masalah lain adalah waktu tunggu pelayanan rawat jalan yang masih melebihi dari standar nasional, yaitu 60 menit. Hasil survey Indeks Kepuasan tahun 2017 yang dilakukan oleh RSUD Dr. Soetomo Surabaya menyebutkan bahwa aspek yang perlu mendapatkan prioritas perbaikan adalah aspek waktu pelayanan. Waktu tunggu pelayanan menjadi hal penting untuk diperhatikan, mengingat pasien yang dirujuk ke RSUD Dr. Soetomo sebagian besar merupakan pasien dengan penyakit berat yang membutuhkan pelayanan dengan segera. Masalah lain juga ditemukan berdasarkan ulasan RSUD Dr. Soetomo Surabaya di google yang mengatakan 
bahwa pelayanan IGD yang disampaikan melalui tulisan adalah kurang dari 6 jam untuk menangani pasien. Namun pada kenyataannya pasien ditangani lebih dari 10 jam dan dibiarkan untuk menunggu di IGD tanpa adanya pemeriksaan lebih lanjut.

\section{Gambar 1. Ulasan RSUD Dr. Soetomo di Google}

Syahri Handoyo

14 ulasan $\cdot 3$ foto

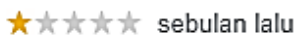

Bikin tulisan maksimal kurang dari 6 jam pasien di tangani. Fakta yang terjadi lebih dari 10 jam pasien di biarkan menunggu di IGD tanpa pemeriksaan lebih lanjut. Pikir pikir lagi pilih rumah sakit

(4) Membantu 6 ף

Sumber: google,2021

3. Rumah Sakit Umum Pusat Dr. Hasan Sadikin Bandung

Berdasarkan Laporan Akuntabilitas Kinerja RSUP Dr. Hasan Sadikin Bandung tahun 2020, nilai yang diperoleh dari survey Indeks Kepuasan Masyarakat Semester 2 Tahun 2020 mempunyai prioritas perbaikan unit pelayanan yang dapat dilihat pada grafik berikut:

\section{Gambar 2. Rekapitulasi Prioritas Perbaikan Pelayanan}

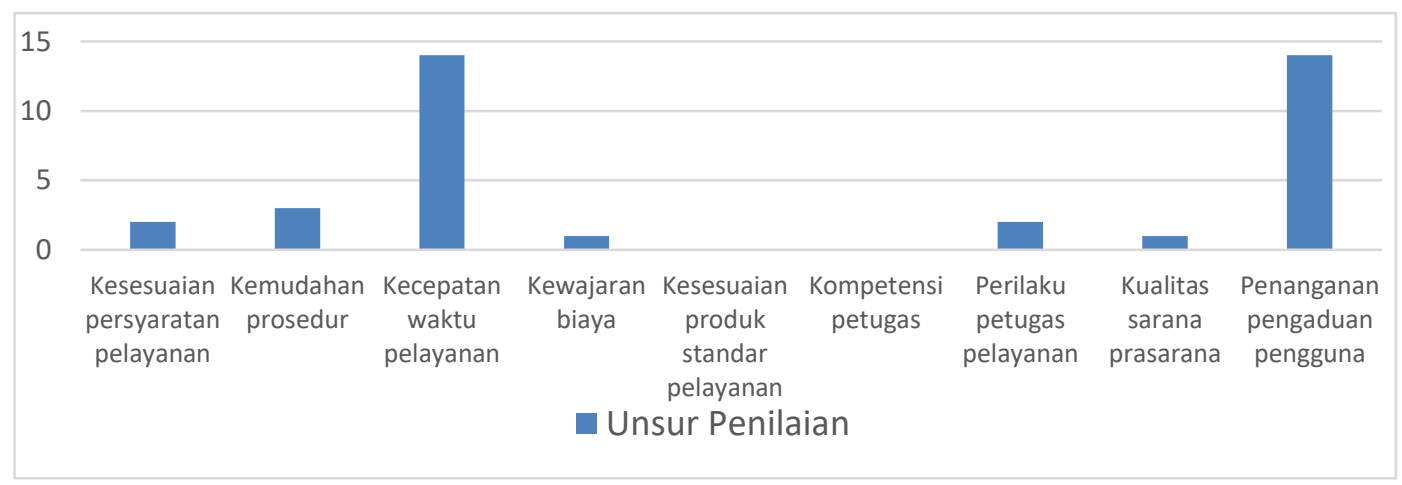

Sumber: Laporan Akuntabilitas Kinerja RSUP Dr. Hasan Sadikin Bandung, 2020

Berdasarkan tabel di atas, dapat diketahui bahwa rekapitulasi prioritas perbaikan pelayanan di RSUP Dr. Hasan Sadikin Bandung yakni kecepatan waktu pelayanan, penanganan pengaduan pengguna, dan kemudahan prosedur. Kecepatan waktu pelayanan masih menjadi masalah sehingga menjadi prioritas perbaikan pelayanan di RSUP Dr. Hasan Sadikin Bandung. Bukti kecepatan pelayanan di RSUP Dr. Hasan Sadikin Bandung, yakni pada persentase pasien yang memenuhi standar Waktu Tunggu Rawat Jalan (WTRJ) $<60$ menit. 
Tabel 3. Capaian Persentase Pasien Yang Memenuhi Standar WTRJ $<60$ Menit

\begin{tabular}{|l|c|c|c|c|c|}
\hline \multirow{2}{*}{$\begin{array}{l}\text { Realisasi presentase } \\
\text { pasien yang } \\
\text { memenuhi standar }\end{array}$} & \multicolumn{2}{|c|}{ Tahun 2019 } & \multicolumn{2}{c|}{ Tahun 2020 } & $\begin{array}{c}\text { Tahun } \\
\mathbf{2 0 2 4}\end{array}$ \\
\cline { 2 - 6 } WTRJ <60 menit & Target & Realisasi & Target & Realisasi & Target \\
\cline { 2 - 6 } & - & - & $77 \%$ & $69.70 \%$ & $90 \%$ \\
\hline Capaian & & - & \multicolumn{2}{|c|}{$90.52 \%$} & $77.44 \%$ \\
\hline
\end{tabular}

Sumber: Laporan Akuntabilitas Kinerja RSUP Dr. Hasan Sadikin Bandung, 2020

Pasien yang memenuhi standar WTRJ $<60$ menit adalah pasien yang dilayani mulai dari pendaftaran sampai dilayani dokter kurang dari 60 menit. Capaian sampai dengan Tahun 2020 adalah 69,70\%. Progres capaian kinerja tahun 2020 terhadap jangka panjang menengah tahun 2024 terpenuhi sebesar 77,44\%. Persentase pasien yang memenuhi WTRJ dibawah 60 menit pada tahun 2020 mengalami perbaikan dibanding dua triwulan sebelumnya. Penyebab klinik dengan capaian WTRJ >60 menit masih dipengaruhi oleh kedatangan pasien yang sering terlambat menyebabkan WTRJ memanjang hingga di atas 60 menit.

\section{B. Tepat (Ketepatan Pelayanan)}

Ketepatan pelayanan memiliki arti bahwa dalam memberikan pelayanan, rumah sakit harus memiliki ketepatan kuantitas, kualitas pelayanan, ketepatan kompetensi pegawai dan ketepatan sasaran sehingga dapat menciptakan pelayanan yang prima untuk masyarakat.

\section{Rumah Sakit Umum Pusat Dr. Kariadi Semarang}

Pandemi Covid-19 ditetapkan sebagai darurat kesehatan masyarakat secara global oleh Organisasi Kesehatan Dunia (WHO) pada tanggal 30 Januari 2020. Adanya pandemi Covid-19 berdampak pada menurunnya kuantitas dan kualitas pelayanan di rumah sakit, yang juga berdampak pada penurunan jumlah pasien dan kunjungan di rumah sakit sehingga pendapatan rumah sakit mengalami penurunan. 


\section{Gambar 3. Grafik Kunjungan Rawat Jalan Tahun 2020}

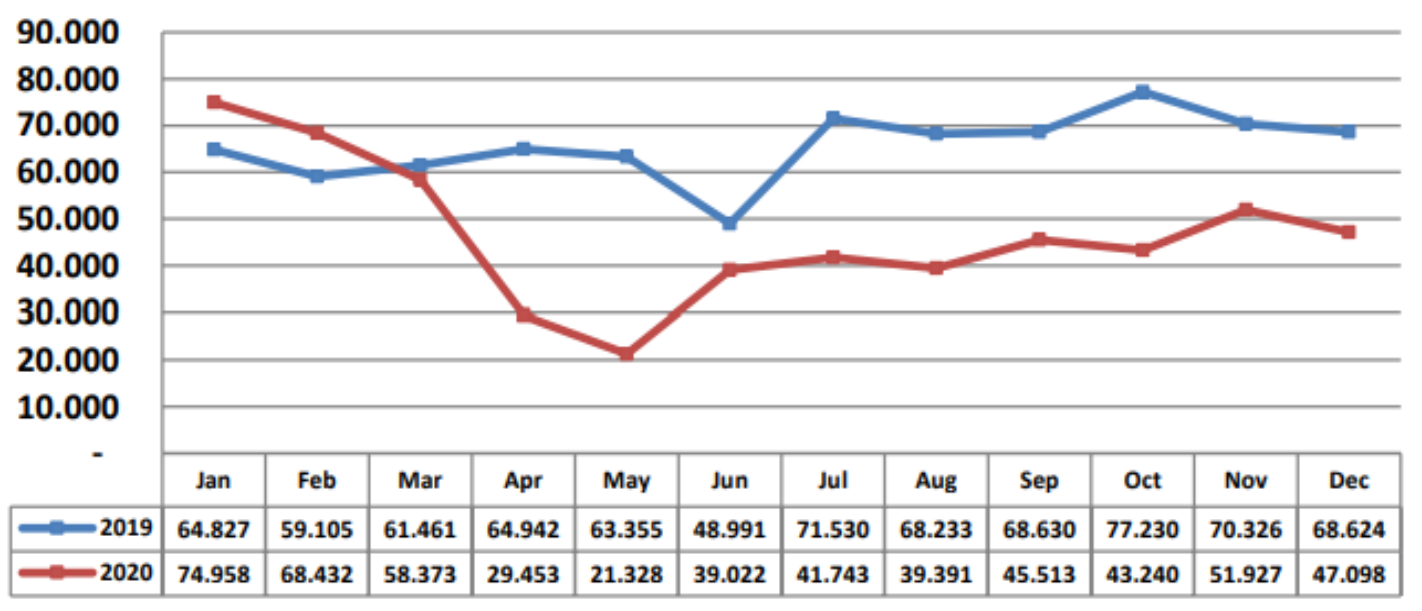

Sumber : Laporan Tahunan RSU Pusat Dr. Kariadi Semarang, 2020

Berdasarkan grafik di atas dijelaskan bahwa rata-rata kunjungan rawat jalan Instalasi Rawat Jalan tahun 2020 sejumlah 249.149 mengalami penurunan 40,05\% dibandingkan tahun 2019 karena adanya pandemi Covid-19. Pelayanan Unggulan yang ada di Rumah Sakit Umum Pusat Dr. Kariadi Semarang juga mengalami penurunan. Menurut Laporan Tahunan RSU Pusat Dr. Kariadi Semarang Tahun 2020, terdapat empat pelayanan unggulan di RSUP Dr. Kariadi pada tahun 2020 mengalami penurunan dibandingkan dengan tahun 2019.

\section{Gambar 4. Grafik Pelayanan Unggulan RSUP Dr. Kariadi Tahun 2020}

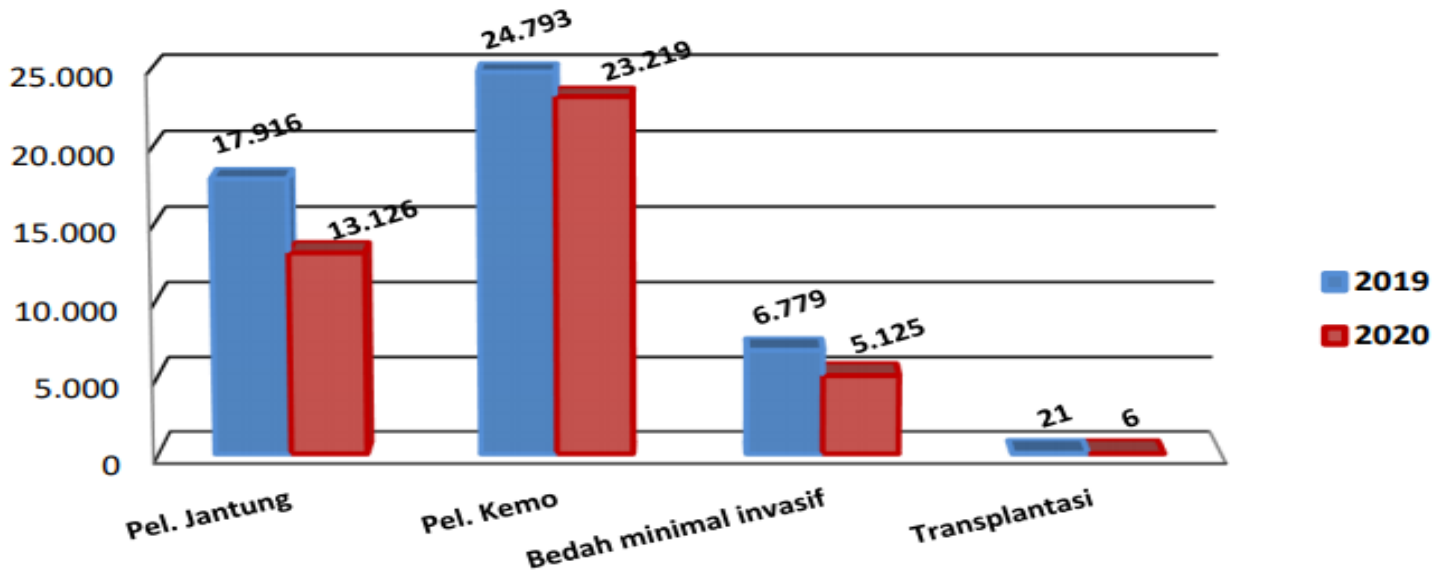

Sumber : Laporan Tahunan RSU Pusat Dr. Kariadi Semarang, 2020

Berdasarkan grafik di atas kegiatan pelayanan unggulan mengalami penurunan karena mulai bulan Maret-Juni terjadi pandemi Covid-19. Oleh karena itu, dapat disimpulkan bahwa kuantitas dan kualitas layanan di RSU Pusat Dr. Kariadi Semarang, 2020 mengalami penurunan akibat adanya Covid-19. Adapun 
tingkat pendidikan para pegawai RSUP Dr. Kariadi dijelaskan pada grafik dibawah ini.

Gambar 5. Tingkat Pendidikan Pegawai RSUP Dr.Kariadi Tahun 2020

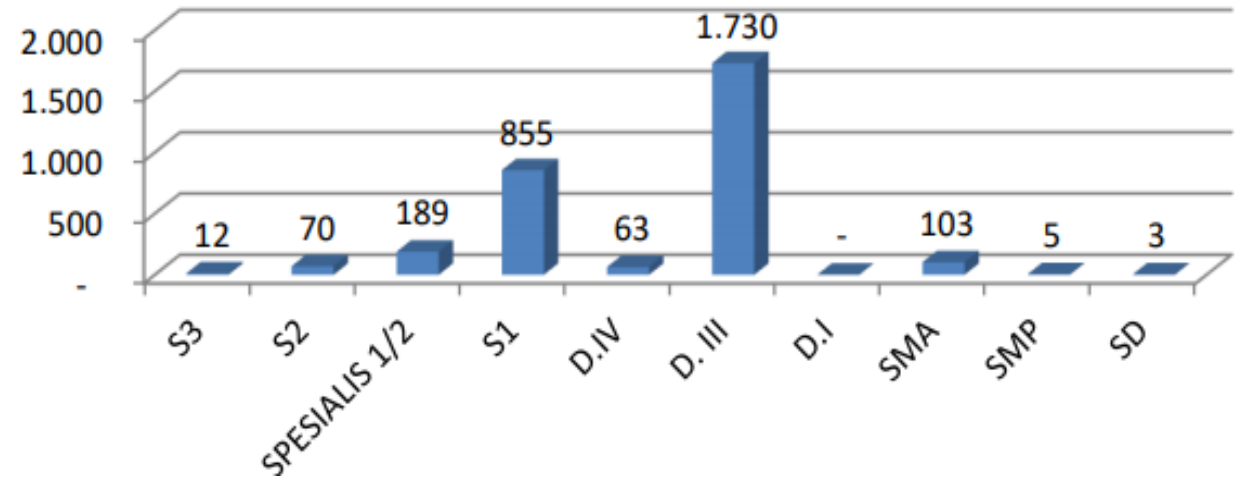

Sumber : Laporan Tahunan RSU Pusat Dr. Kariadi Semarang, 2020

Grafik di atas menjelaskan bahwa tingkat pendidikan pegawai RSUP Dr. Kariadi paling banyak diisi dengan pendidikan Diploma III (DIII) sebanyak 1.730. Berdasarkan kondisi ketenagaan per 31 Desember 2020, masih ada beberapa jenis tenaga yang mengalami kekurangan seperti perawat disebabkan adanya pandemi Covid-19. Berdasarkan capaian kontrak kinerja tahun 2020 dalam Laporan Tahunan RS.Kariadi Tahun 2020 menyatakan bahwa pencapaian standard kompetensi seluruh pegawai sebesar $80,82 \%$ sehingga dikategorikan baik meskipun belum maksimal. Hal tersebut karena selama tahun 2020 beberapa pelatihan kompetensi khususnya yang sudah dijadwalkan tidak dapat dilaksanakan karena adanya pandemi Covid-19.

Pada pelaksanaanya, beberapa pegawai belum mengimplementasikan budaya kerja dengan baik. Hal tersebut dibuktikan dengan adanya laporan pasien yang dimuat dalam beritajateng.net (2020), di mana pasien diminta untuk menunggu selama enam hari setelah mendaftar di Instalasi Gawat Darurat karena untuk mendapatkan kamar inap sangat sulit, tetapi petugas tiba-tiba menjelaskan tidak adanya kamar kosong.

Ketepatan pelayanan selanjutnya adalah ketepatan sasaran, RSUP Dr.Kariadi dinilai sudah memberikan pelayanan yang tepat sasaran. Hal tersebut dibuktikan dengan Indeks kepuasan pelanggan mencapai 80\%, sedangkan penanganan pengaduan/persentase pengaduan mencapai $100 \%$ menurut Laporan Tahunan RSU Pusat Dr. Kariadi Semarang (2020) sehingga membuat ketepatan sasaran ini 
menjadi kelebihan dari RSU Pusat Dr. Kariadi Semarang. RSUP Dr. Kariadi Semarang juga memiliki kelebihan dalam memberikan edukasi kepada masyarakat sebagai bentuk memperjuangkan ketepatan sasaran, yaitu dengan mengadakan edukasi secara online melalui media sosial seperti facebook, instagram, twitter serta menggunakan banner yang dipasang di lingkungan rumah sakit dan pelatihan dengan sasaran masyarakat mengenai pelayanan Covid-19, diantaranya Novel Coronavirus oleh Komite PPI.

2. Rumah Sakit Umum Daerah Dr. Soetomo Surabaya

RSUD Dr.Soetomo mempunyai tugas melaksanakan upaya kesehatan secara berdayaguna dan berhasilguna dengan mengutamakan upaya penyembuhan dan pemulihan. Oleh karena itu, dibutuhkan ketepatan kuantitas dan kualitas pelayanan. Adanya pandemi Covid-19 sejak bulan Maret 2020 membuat kegiatan pelayanan RSUD Dr. Soetomo teralihkan untuk pengembangan ruang isolasi dalam rangka penanganan Covid-19. Pengalihan tersebut menyebabkan penurunan kunjungan rawat jalan mencapai 11,8\%. Hal tersebut karena adanya pandemi Covid-19 sehingga persepsi pasien dan keluarga yang cenderung menghindari rumah sakit karena ketakutan akan tertular Covid-19. Oleh karena itu, ketepatan kuantitas dan kualitas pelayanan dinilai belum maksimal karena mengalami penurunan. Menurut Laporan Evaluasi Kinerja Internal RSUD Dr. Soetomo Tahun 2020 dapat diketahui bahwa nilai Indeks Kepuasan Masyarakat (IKM) dan kompetensi pelaksana terhadap pelayanan RSUD Dr. Soetomo Surabaya adalah 77,95 dengan nilai mutu pelayanan B (Baik) meskipun belum maksimal.

3. Rumah Sakit Umum Pusat Dr. Hasan Sadikin Bandung

RSUP Dr. Hasan Sadikin sebagai rumah sakit rujukan menyelenggarakan pelayanan secara terpadu. Adanya keinginan yang kuat untuk memberikan pelayanan yang prima kepada masyarakat membutuhkan ketepatan pelayanan. Berdasarkan survei yang dilakukan oleh RSUP Dr. Hasan Sadikin Bandung kepada masyarakat (responden) menunjukkan bahwa ketepatan dalam hal kualitas layanan serta ketepatan kompetensi pegawai masih belum maksimal yang dapat dilihat pada tabel di bawah ini. 
Tabel 5. Saran dan Masukan Masyarakat Tahun 2020

\begin{tabular}{|c|l|l|l|}
\hline No & Lokasi & Unit Pelayanan & \multicolumn{1}{c|}{ Saran dan Masukan } \\
\hline 1. & $\begin{array}{l}\text { Rawat } \\
\text { jalan }\end{array}$ & Poliklinik anak & $\begin{array}{l}\text { Antrian kadang tidak sesuai lebih mengutamakan } \\
\text { yang kenal }\end{array}$ \\
\hline 2. & & Poliklinik bedah & $\begin{array}{l}\text { Toilet kotor } \\
\text { Obat mahal }\end{array}$ \\
\hline 3. & & Poliklinik dalam & $\begin{array}{l}\text { - Pelayanan pertanyaan kurang direspon baik, khusus } \\
\text { pelayanan oleh yang sudah tua } \\
\text { - Kurangnya informasi }\end{array}$ \\
\hline 4. & & Poliklinik gigi & $\begin{array}{l}\text { - Informasi lebih ditingkatkan } \\
\text { - Kurang sinkon informasi dari dokter dan perawat }\end{array}$ \\
\hline 5. & & $\begin{array}{l}\text { Poliklinik } \\
\text { obgyn }\end{array}$ & $\begin{array}{l}\text { - Percepat lagi waktu pelayanan } \\
\text { - Lebih ramah lagi susternya } \\
\text { - Ditambah lagi pegawainya } \\
\text { - Disediakan ruang tunggu }\end{array}$ \\
\hline
\end{tabular}

Sumber : Laporan Akuntabilitas Kinerja RSUP Dr. Hasan Sadikin Bandung, 2020

Berdasarkan hasil survey Indeks Kepuasan Masyarakat (IKM) tahun 2020 didapatkan beberapa permasalahan yang menjadi keluhan pelanggan di unit rawat inap. Beberapa permasalahan tersebut adalah prosedur pelayanan di masa pandemi prosedur tindakan/operasi), tanggung jawab dan kompetensi petugas seperti penanganan pasien yang tidak memberikan pelayanan secara jelas dan sopan sehingga indeks kepuasan masyarakat tidak mencapai target serta ketepatan sasaran dirasa kurang maksimal yang dapat dijelaskan pada tabel di bawah ini.

Tabel 6. Indeks Kepuasan Masyarakat Terhadap Pelayanan Tahun 2019-2020

\begin{tabular}{|c|c|c|c|c|}
\hline $\begin{array}{c}\text { Realisasi Indeks } \\
\text { Kepuasan Masyarakat }\end{array}$ & \multicolumn{2}{|c|}{ Tahun 2019 } & \multicolumn{2}{c|}{ Tahun 2020 } \\
\cline { 2 - 5 } & Target & Realisasi & Target & Realisasi \\
\cline { 2 - 5 } & 82 & 82,39 & 83 & 76,67 \\
\hline Capaian & \multicolumn{2}{|c|}{$100,48 \%$} & \multicolumn{2}{c|}{$92,37 \%$} \\
\hline
\end{tabular}

Sumber : Laporan Akuntabilitas Kinerja RSUP Dr. Hasan Sadikin Bandung, 2020

Berdasarakan tabel di atas, secara keseluruhan kualitas kinerja pelayanan bagi masyarakat pengguna jasa RSUP Dr. Hasan Sadikin Tahun 2020 dapat dikategorikan baik namun perolehan Indeks Kepuasan Masyarakat (IKM) realisasi belum mencapai taget, yaitu sebesar 76,67 dari target yang telah ditetapkan sebesar 83. Dapat disimpulkan bahwa ketepatan pelayanan RSUP Dr. Hasan Sadikin Bandung dinilai masih belum baik karena ketepatan kualitas pegawai dan sasaran belum berjalan dengan maksimal. 
C. Akurat

1. Rumah Sakit Umum Pusat Dr. Kariadi Semarang

Informasi mengenai pelayanan kesehatan yang mudah diakses melalui berbagai media yang telah diterapkan di RSUP Dr. Kariadi ini merupakan wujud dari penerapan indikator budaya pelayanan prima untuk meningkatkan kualitas pelayanan publik yang merupakan komponen pengungkit dari Zona Integritas WBK dan WBBM. Di balik kelancaran akses masyarakat guna mengetahui informasi mengenai RSUP Dr. Kariadi, rumah sakit tersebut memiliki kekurangan dalam bidang pelayanan yang diberikan pihak rumah sakit terhadap pasien. Adanya laporan pasien yang dimuat dalam beritajateng.net di mana pasien diminta untuk menunggu selama enam hari setelah mendaftar di Instalasi Gawat Darurat karena untuk mendapatkan kamar inap sangat sulit dan petugas menjelaskan tidak ada kamar kosong.

Kondisi serupa juga dikeluhkan oleh pasien hasil rujukan dari Rumah Sakit lain ke RSUP Dr. Kariadi namun setelah berada di RSUP Dr.Kariadi pasien yang menggunakan fasilitas kesehatan BPJS tersebut mengeluh tidak membuahkan hasil. Selain itu, juga terdapat beberapa suster atau tenaga kesehatan RSUP Dr. Kariadi yang bersikap galak atau kurang ramah dan kurang tepatnya penanganan dokter (tidak sesuai dengan jadwal pelayanan) terhadap pasien.

2. Rumah Sakit Umum Daerah Dr. Soetomo Surabaya

Kemampuan RSUD Dr. Soetomo Surabaya dalam memberikan pelayanan kepada pasien tercermin dari adanya ulasan yang disampaikan melalui google. Ulasan yang disampaikan berisi adanya perawat yang bertugas dalam menyampaikan informasi dengan nada yang tinggi, padahal keluarga pasien merupakan orang yang awam dan belum mengetahui cara untuk memasukkan susu atau obat melalui selang infus. Adapun bukti ulasan tersebut dapat dilihat pada gambar berikut. 


\section{Gambar 6. Ulasan Masyarakat}

Victoria Pramudiant

1 ulasan

$\star \star \star * \star * \star *$ sebulan lalu

minta tolong untuk para perawat atau suster yg bertugas, jangan suka nyolot kalau ngomong ke

keluarga pasien. saya orang awam yg masih blm mengerti bagaimana cara memasukkan susu atau obat ke pasien lewat selang infus. minta tolong $2 x$ utk dibantu, dibilang manjaa dan keterbatasan org (perawat). sedangkan saya liat sendiri, suster pada ngrumpi di ruang istirahat. minta tolonggg dengann sangattt dan dengan rendahh hatii, bersikaplah ramah bantulah keluarga pasien yang ga tau apa2, jujur sayaa sangatt kecewa dengan pelayanan nyaaa.

mohon untuk diperbaiki kedepan nyaa thanks

Sumber : Google,2021

Ulasan lain menyatakan bahwa perawat dan customer service loket yang mudah marah dan menurut pengguna pelayanan, perawat dan customer service tersebut tidak mementingkan sopan santun pada saat menyampaikan informasi kepada pengguna. Ulasan tersebut dapat dilihat pada gambar berikut:

\section{Gambar 7. Ulasan Masyarakat}

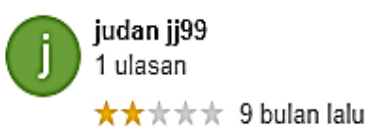

Banyak perawat dan cs antrian loket mudah marah dan tidak mementingkan sopan santun jika pihak dr Soetomo membaca harap segera menindaklanjuti seharusnya jika pihak keluarga pasien tidak paham akan sesuatu di arahkan dengan bahsa yang lembut nan sopan tidak di maki di depan umum saya sangat merasa kecewa terutama loket radiologi B 6 pukul 12.02 tanggal 21 September 2020 entah siapa yang jaga tpi saya sangat merasa kecewa

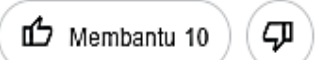

Sumber : Google, 2021

3. Rumah Sakit Umum Pusat Dr. Hasan Sadikin Bandung

Kemampuan rumah sakit untuk memberikan pelayanan sesuai dengan yang dijanjikan secara akurat dan terpercaya dirasa penting agar menciptakan kepuasan pelayanan bagi pasien. Pada kenyataannya, berdasarkan ulasan google menyatakan bahwa Rumah Sakit Umum Pusat Dr. Hasan Sadikin Bandung dalam hal pemberian pelayanan kepada pasien, untuk transparansi yang diberikan mengenai penyakit dari keluarga pasien hanya disimpulkan secara sepihak oleh rumah sakit, pihak keluarga yang meminta bukti atas penyakit tersebut tidak diberikan oleh pihak rumah sakit. Adapun ulasan tersebut dapat dilihat pada gambar berikut: 


\section{Gambar 8. Ulasan Masyarakat}

Wiwi Juwanti

W) 3 ulasan

$\star \star * * *$ seminggu lalu $\longdiv { \text { BARU } }$

Ibu saya dirawat disana dan meninggal, disimpulkan positif covid, tapi saat keluarga saya minta bukti nya ga dikasih, padahal itu hak keluarga saya, kenapa pihak rs berani menyimpulkan bahwa ibu saya positif covid jika tidak ada bukti. Dari pihak rs mengatakan bahwa ibu saya akan dimandikan dan di sholatkan disana, tapi nyatanya saat jenazah datang, belum disholatkan, saya merasa sangat kecewa atas perlakuan terhadap jenazah ibu saya, dimakam kan dengan tidak layak. Jika sengaja mengcovidkan ibu saya demi kepentingan sesuatu, betapa rendahnya hidup orang2 pihak rs, semoga kematian kalian lebih2 diperlakukan tidak adil daripada ibu saya.

\section{化 Membantu q}

Sumber : Google, 2021

Ulasan dari google lainnya menyatakan bahwa pelayanan Rumah Sakit Umum Pusat Dr. Hasan Sadikin Bandung buruk, pasien mengatakan pernah dirujuk dengan penyakit usus buntu, namun perlakuan dari dokter lebih baik untuk kembali ke rumah tanpa diberikan penanganan lebih lanjut. Dapat disimpulkan bahwa keakuratan pelayanan masih belum maksimal seperti ulasan dibawah ini.

\section{Gambar 9. Ulasan Masyarakat}

Orang Sunda Bandung

1 ulasan

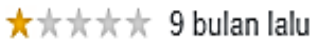

Pelayanan nya buruk saya pernah di rujuk ke rs Hs dengan penyakit usus buntu dikata dokter nya baik baik di auruh pulang ajah padahal saya udh hampir mati Kesakitan. akhirnya saya pindah ke rs Avisena langsung ke igd tanpa antrian dan dilayani cepat 1 jam oprasi beres operasi.

\section{Membantu 2 ף}

Sumber : Google,2021

\section{Berkualitas}

Pelayanan prima dapat diwujudkan jika pelayanan berkualitas. Pelayanan berkualitas memiliki pengertian bahwa pelayanan tersebut harus memiliki ketersediaan sarana dan prasarana yang berkualitas termasuk penyediaan sarana dan tekonologi telekomunikasi dan informatika.

1. Rumah Sakit Umum Pusat Dr. Kariadi Semarang

Menurut hasil Laporan Tahunan RSU Pusat Dr. Kariadi Semarang Tahun 2020 menyatakan bahwa penyediaan fasilitas sarana dan prasarana untuk difabel sebagai salah satu area pelayanan publik rumah sakit diharapkan mampu 
memberikan pelayanan yang baik bagi penyandang disabilitas. Fasilitas bagi difabel seperti penandaan tempat parkir khusus difabel, akses masuk dimulai pintu masuk sampai dengan tempat pelayanan, kamar mandi yang berada di Paviliun Garuda, Rawat Jalan, masjid, Instalasi Onkologi. Penyediaan fasilitas khusus difabel menjadikan kelebihan dari sarana dan prasarana yang dimiliki oleh RSU Pusat Dr. Kariadi.

Ditengah Pandemi Covid-19, RSUP Dr. Kariadi juga telah melakukan pengujian dan kalibrasi alat kesehatan secara periodik dan terjadwal yang bertujuan untuk meningkatkan mutu pelayanan kesehatan di RS (Laporan Tahunan RSU Pusat Dr. Kariadi Semarang, 2020). Disamping itu, sarana prasarana penunjang pelayanan Covid-19 seperti kelengkapan APD, obat-obatan (vitamin), suplemen makanan serta fasilitas lainnya juga sudah tersedia. Pada kondisi pandemi Covid19, untuk memenuhi kebutuhan masyarakat yang akan berobat rawat jalan di rumah sakit maka RSU Pusat Dr. Kariadi Semarang mengembangkan digitalisasi layanan dengan mengoperasionalkan Klinik Virtual sebagai bentuk penyediaan sarana dan tekonologi telekomunikasi dan informatika. (Laporan Tahunan RSU Pusat Dr. Kariadi Semarang,2020).

RSUP Dr. Kariadi menurut hasil Laporan Tahunan RSU Pusat Dr. Kariadi Semarang Tahun 2020 telah menerapkan pengelolaan air limbah. Saat ini, untuk instalasi pengolahan air limbah berada di Rajawali, Garuda, Sentral (dekat Instalasi Kasuari). Hasil pengolahan air limbah cair dari bulan Januari-Desember 2020 sudah memenuhi standar baku mutu lingkungan. Adapun sarana dan prasarana yang masih harus diperbaiki, yaitu pengadaan alat terkait peningkatan mutu pelayanan terutama untuk pelayanan Covid-19. Renovasi perluasan ruangan untuk kebutuhan pelayanan Covid-19, kebutuhan komputer PC dan laptop untuk rekam medik elektronik juga masih kurang serta sistem keamanan di rumah sakit belum terpantau semua dengan CCTV. Berdasarkan penjelasan di atas, dapat disimpulkan bahwa penyediaan sarana dan prasarana di RSU Pusat Dr. Kariadi Semarang Tahun 2020 dinilai sudah baik meskipun terdapat beberapa sarana dan prasaran yang harus diperbaiki. 
2. Rumah Sakit Umum Daerah Dr. Soetomo Surabaya

Pada pelaksananya, sarana dan prasaran yang dimiliki oleh Rumah Sakit Umum Daerah Dr. Soetomo Surabaya dinilai oleh masyarakat eksternal kurang baik. Hal tersebut dijelaskan pada tabel di bawah ini.

Tabel 7. Indeks Kepuasan Masyarakat Terhadap Pelayanan Tahun 2020

\begin{tabular}{|c|l|c|c|l|}
\hline No & \multicolumn{1}{|c|}{ Aspek Pelayanan } & Nilai IKK & $\begin{array}{c}\text { Mutu } \\
\text { Pelayanan }\end{array}$ & \multicolumn{1}{|c|}{ Kinerja } \\
\hline 1. & Persyaratan & 76,50 & C & Kurang Baik \\
\hline 2. & Prosedur & 80,00 & B & Baik \\
\hline 3. & Waktu Pelayanan & 77,50 & B & Baik \\
\hline 4. & Biaya & 75,00 & C & Kurang Baik \\
\hline 5. & $\begin{array}{l}\text { Produk Spesifikasi } \\
\text { Pelayanan }\end{array}$ & 80,00 & B & Baik \\
\hline 6. & Kompetensi Pelayanan & 80,25 & B & Baik \\
\hline 7. & Perilaku Pelaksana & 80,00 & B & Baik \\
\hline 8. & Penanganan pengaduan & 75,00 & C & Kurang Baik \\
\hline 9. & Sarana dan Prasarana & $\mathbf{7 5 , 2 5}$ & C & Kurang Baik \\
\hline 10. & $\begin{array}{l}\text { Jaminan Mutu dan } \\
\text { Keselamatan Pasien }\end{array}$ & 80,00 & B & Baik \\
\hline
\end{tabular}

Sumber : Laporan Evaluasi Kinerja Internal RSUD Dr. Soetomo,2020

Berdasarkan tabel di atas dapat diketahui bahwa nilai Indeks sarana dan prasarana pada Pelayanan RSUD Dr. Soetomo Surabaya adalah 75,25 dengan nilai mutu pelayanan $\mathrm{C}$ (kurang baik) sehingga dapat disimpulkan bahwa kualitas sarana dan prasana terkategori kurang baik seperti contohnya adalah RSUD Dr. Sotomo masih kekurangan alat kesehatan di mana beberapa alat kesehatan yang ditujukan untuk back up alat mengalami kerusakan dan rencana pengembangan pelayanan tidak berjalan.

3. Rumah Sakit Umum Pusat Dr. Hasan Sadikin Bandung

Pelayanan unggulan dari RSUP Dr. Hasan Sadikin, yaitu pelayanan kedokteran nuklir, pelayanan teknologi reproduksi berbantu, pelayanan jantung, pelayanan onkologi \& infeksi, pelayanan transplantasi ginjal dan pelayanan bedah minimal invasif. (Laporan Akuntabilitas Kinerja RSUP Dr. Hasan Sadikin Bandung, 2020)

Terdapat beberapa sarana dan prasarana yang harus diperbaiki menurut Laporan Akuntabilitas Kinerja RSUP Dr. Hasan Sadikin Bandung Tahun 2020, yaitu ketidaktersediaan alat untuk tata laksana pasien, misal Lymph Compression Therapy rusak padahal sudah diajukan sejak tahun 2019 namun belum dipenuhi, 
keterbatasan kapasitas ruang intensif juga sebagai salah satu faktor mengakibatkan waktu tunggu efektif memanjang. Terdapat beberapa obat kemoterapi yang tidak tersedia dan pasien tidak bersedia untuk disubstitusi dengan obat setara terapi sehingga dirasa perlu untuk memperbaiki standarisasi sarana dan prasarana. Berdasarkan penjelasan di atas dapat disimpulkan bahwa kualitas sarana dan prasarana di Rumah Sakit Umum Pusat Dr. Hasan Sadikin Bandung belum baik.

\section{KESIMPULAN}

Pelayanan prima pada rumah sakit dapat diartikan sebagai pelayanan yang diberikan kepada pasien berdasarkan standar kualitas untuk memenuhi kebutuhan dan keinginan pasien. Bentuk pelayanan prima yang dilakukan oleh Rumah Sakit Umum Pusat Dr. Kariadi Semarang, Rumah Sakit Umum Daerah Dr. Soetomo Surabaya dan Rumah Sakit Umum Pusat Dr. Hasan Sadikin Bandung adalah mengenai kecepatan pelayanan, ketepatan pelayanan, pelayanan yang akurat dan kualitas pelayanan.

Kelebihan yang dimiliki oleh RSU Pusat Dr. Kariadi Semarang adalah pada kualitas sarana dan prasana, salah satunya, yaitu penyediaan fasilitas sarana dan prasarana yang digunakan untuk difabel, sedangkan kekurangan yang dimiliki oleh RSU Pusat Dr. Kariadi Semarang, yaitu kecepatan pelayanan. Berbeda dengan RSU Daerah Dr. Soetomo yang memiliki kelebihan dalam hal ketepatan pelayanan di mana indeks kepuasan masyarakat tahun 2020 mencapai 77,95 dengan nilai mutu pelayanan baik, sedangkan kekuarangan yang dimiliki oleh RSU Daerah Dr. Soetomo adalah kecepatan pelayanan, di mana waktu tunggu pelayanan rawat jalan yang masih melebihi dari standar nasional, yaitu 60 menit. Pada RSU Pusat Dr. Hasan Sadikin Bandung memiliki kelebihan dalam ketepatan pelayanan dalam bentuk ketepatan kompetensi pegawai, sedangkan kekurangan yang dimiliki adalah dalam kecepatan pelayanan yang memiliki capaian sejumlah 69,70\% dengan mutu pelayanan yang kurang baik. Oleh karena itu, kecepatan pelayanan menjadi prioritas perbaikan yang mesti dilakukan oleh ketiga rumah sakit tersebut untuk mewujudkan pelayanan yang prima.

\section{Saran}

Berdasarkan kesimpulan yang telah diuraikan di atas maka rekomendasi yang dapat diberikan adalah: 
1. Pihak rumah sakit dapat melakukan pengukuran indeks kepuasan masyarakat secara berkala, yakni melalui survei secara periodik setiap bulan. Hal tersebut bertujuan agar dapat dijadikan bahan penilaian terhadap unsur pelayanan yang masih perlu perbaikan dan menjadi pendorong setiap unit penyelenggara pelayanan untuk meningkatkan kualitas pelayanannya.

2. Peningkatan kualitas sumber daya manusia yang ada di Rumah Sakit Umum Pusat Dr. Kariadi Semarang, Rumah Sakit Umum Daerah Dr. Soetomo Surabaya dan Rumah Sakit Umum Pusat Dr. Hasan Sadikin Bandung. Peningkatan kompetensi diperlukan agar menciptakan petugas pelayanan yang berkompetensi tinggi sehingga menciptakan pelayanan yang prima.

\section{DAFTAR PUSTAKA}

Laporan Akuntabilitas Kinerja RSUP Dr. Hasan Sadikin Bandung Tahun 2020.

Laporan Akuntabilititas Kinerja RSUP.Dr Kariadi Tahun 2020.

Laporan Tahunan RSU Pusat Dr. Kariadi Semarang Tahun 2020.

Laporan Rencana Strategis RSUD Dr. Soetomo Tahun 2019-2024.

Laporan Evaluasi Kinerja Internal RSUD Dr. Soetomo Tahun 2020.

Nazir, M. (2014). Metode Penelitian. Bogor: Ghalia Indonesia.

Purnamasari, A., dan Kushandajani. (2019). Peningkatkan Pelayanan Publik RSUP Dr. Kariadi Semarang Yang Akuntabel Dan Anti Korupsi Dalam Mempertahankan Zona Integritas Wilayah Bebas Korupsi Dan Wilayah Birokrasi Bersih Melayani. Jurnal Ilmiah Ilmu Pemerintahan, 51-60.

Rahmayanty, N. (2010). Manajemen Pelayanan Prima. Yogyakarta: Graha Ilmu.

Sekhon, H. S., Al-Eisawi, D., Roy, S. K., dan Pritchard. (2015). Service excellence in UK retail banking: Customers' perspectives of the important antecedents. International Journal of Bank Marketing, 904-921.

Sesrianty, Vera dkk. (2019). Analisa Kepuasan Pasien Terhadap Mutu Pelayanan Keperawatan. Jurnal Kesehatan Perintis, 35-40.

Setyobudi dan Daryanto. (2014). Konsumen dan Pelayanan Prima. Yogyakarta: Gava Media.

Suminar, Ratna, dan Apriliawati. (2017). Pelayanan Prima Pada Orang Tua Siswa Di Sempoa Sip Tc Paramount Summarecon. Jurnal Sekretaris, 1-15.

Surjadi. (2009). Pengembangan kinerja pelayanan publik. Bandung: Refika Aditama.

Suryati, L. (2015). Manajemen Pemasaran Yogyakarta. Yogyakarta: CV Budi Utama. 